\title{
Genetic and historical studies on the origin of Norway spruce in Białowieża Primeval Forest in Poland
}

\author{
Monika Dering • Andrzej Misiorny • \\ Andrzej Lewandowski · Adolf Korczyk
}

Received: 21 July 2010/Revised: 15 March 2011/Accepted: 29 March 2011/Published online: 22 April 2011

(C) The Author(s) 2011. This article is published with open access at Springerlink.com

\begin{abstract}
Białowieża Primeval Forest lies within the boreal part of the Norway spruce range, which, according to pollen data, was formed by a refugium located in the Russian Upland. However, recent genetic studies have indicated that spruce from the Eastern Carpathian refugium also occurs in Białowieża Forest. In order to investigate whether the Norway spruce from the Eastern Carpathian refugium migrated naturally into the boreal part of the Norway spruce range, we assessed the refugial origin of 234 of the oldest Norway spruce individuals from Białowieża Forest using mitochondrial marker mt15-D02. Out of the trees that we studied, $64.8 \%$ carried mitotype 1, which is specific to the Carpathian refugium, while $35.2 \%$ had mitotype 3, specific to the Russian refugium. Our genetic analysis, combined with historical data on forest management in this part of Europe, argues for a natural contribution of spruce from the Eastern Carpathian refugium during postglacial recolonization of Białowieża Primeval Forest.
\end{abstract}

Keywords Norway spruce - Mitochondrial DNA . Refugium · Białowieża Forest · Forest management

Communicated by G. Brazaitis.

M. Dering $(\bowtie) \cdot A$ A. Misiorny · A. Lewandowski Institute of Dendrology, Polish Academy of Sciences, Parkowa Street 5, 62-035 Kórnik, Poland

e-mail: mdering@man.poznan.pl

A. Korczyk

Bialystok University of Technology, Wiejska Street 5A, 15-351 Białystok, Poland

\section{Introduction}

Białowieża Forest is located within the boreal part of the Norway spruce range, in the vicinity of the hybrid zone between the boreal and southern spruce ranges representing the two different postglacial refugia (Latałowa and van der Knaap 2006; Środoń and Tobolski 2007; Dering 2008). This forest complex resembles the virgin lowland forests that originally covered Central Europe (Faliński 1968). According to pollen data, Białowieża was colonized with spruce from a refugium in the Middle Russian Upland (Latałowa and van der Knaap 2006; Tollefsrud et al. 2009). Genetic data support this finding but additionally indicate that the Norway spruce in Białowieża comes from the Eastern Carpathian refugium as well (Dering 2008). If so, Białowieża Forest would be part of the hybrid zone between the Russian and Eastern Carpathian refugia.

However, the palynologic studies of Latałowa and Van der Knaap (2006) do not support the Holocene expansion of spruce from the Carpathians so far to the north. In these authors' opinion, the Norway spruce from the Carpathian refugium is mostly a montane ecotype. The ecophysiological characteristics of the Norway spruce from the Carpathian refugium are reflected in the complex dynamics of its range development in southern Poland; there was a very rapid shift in northwest range limits 8 - to 10-thousand years before the present (ka BP) during the colonization of mountain areas, and subsequently, very slow immigration into the uplands of southern Poland (Latalowa and van der Knaap 2006). The Norway spruce from the Russian refugium colonized northeastern Poland much later; the most vigorous expansion is believed to have occurred in the last two millennia. Pollen and morphological data suggest that the northern spruce was more 
expansive than the southern spruce (Giertych 1973; Latałowa and van der Knaap 2006).

Studies of the genetic structure of Norway spruce using mitochondrial DNA markers have shown clear separation between populations from boreal and Central European ranges (Sperisen et al. 2001; Tollefsrud et al. 2008). Based on marker nad $1 \mathrm{~b} / \mathrm{c}$, a hybrid zone between recolonization pathways originated in Russian Upland refugium and Carpathian refugium was delineated within the area previously defined as the "spruceless zone" (Dering and Lewandowski 2009). Limited resolution in this marker did not allowed for detailed inferences about the genetic structure and origin of Norway spruce populations in Białowieża Forest. More insight was gained with marker mt15-D02 previously used by Maghuly et al. (2006) in studies of geographic pattern of genetic differentiation of spruce in Alps. Except two size variants described by Maghuly et al. (2006), Litkowiec et al. (2009) found additional fragment in populations from north-eastern Poland. The distribution of mitotypes was not random and showed geographic pattern. Mitotype 1 was specific to populations located in southern Poland that historically derive from Carpathian refugium, and a new mitotype 3 occurred in populations from north-eastern Poland that originate in Russian Upland refugium; mitotype 2 common in Alps was recognize as non-native to Poland.

The striking disagreement between palynologic and genetic data in relation to postglacial history of Norway spruce in Białowieża requires explanation. Our objective was to assess mtDNA polymorphism aiming to investigate the refugial origin of the oldest Norway spruce individuals in Białowieża Forest. Results of the genetic studies using marker mt15-D02 were combined with the information about the history of management in Białowieża in order to answer the following questions: (1) Which refugium was the source of most of the Norway spruce in Białowieża? (2) What is the status of the Eastern Carpathian Norway spruce in Białowieża? Is it the result of spontaneous migration, or did its presence involve the planting of foreign reproductive material?

\section{Materials and methods}

Study site and sampling

The material for this study originated from the Białowieża Forest complex, a woodland straddling the border between Poland and Belarus $\left(52^{\circ} 40^{\prime} \mathrm{N}, 23^{\circ} 50^{\prime} \mathrm{E}\right)$. The best-preserved fragments of forest, which have retained a primeval character, are protected within the Białowieża National Park (Białowieża NP).
The information on the location of the oldest Norway spruce individuals in Białowieża Forest was obtained from local foresters. Only Norway spruce individuals with diameter at breast height $\geq 70 \mathrm{~cm}$ were included in sampling. Forty-three old single trees and 191 old trees in groups were sampled, totaling to 234 trees in this study. Material was collected in the productive stands, partly protected areas and within the strict protection area of Białowieża NP (group G5, Fig. 1; Table 2). The needles were collected by shooting. In addition, 15 Norway spruce populations from different areas in the European range of the species were also included. In total, 182 Norway spruce individuals from Finland, Sweden, Estonia, Latvia, Ukraine, Romania, and Germany were analyzed. Detailed information about sampled individuals is presented in Tables 1,2 and 3.

\section{Genetic analysis}

Total genomic DNA was extracted from needles with the Qiagen DNeasy Plant Mini Kit. The maternally inherited mitochondrial locus $m t 15-D 02$ was chosen for the analysis, because its refugial specificity in the Norway spruce was proven by Dering (2008) and Litkowiec et al. (2009). Marker $m t 15-D 02$ exhibits insertion/deletion (indel) polymorphism (Maghuly et al. 2006). Amplification of the region mt15-D02 (GenBank accession number AY897577; primer F: 5'-TATCTGACTTGCCTTATC-3'; primer R: 5'ATCCGAATACATACACC- $3^{\prime}$ ) was conducted in total volume of $25 \mu \mathrm{l}$ using $1 \times$ PCR buffer (Novazym), $2.5 \mathrm{mM}$ $\mathrm{MgCl}_{2}, 0.2 \mathrm{mM}$ dNTPs, 4 pmol each of primers, $0,5 \mathrm{U}$ of VivaTaq Polymerase (Novazym), and 30-50 ng of template DNA. PCR-cycling conditions consisted of an initial denaturation step of $95^{\circ} \mathrm{C}$ for $15 \mathrm{~min}$, followed by 40 cycles of $1 \mathrm{~min}$ at $95^{\circ} \mathrm{C}, 1 \mathrm{~min}$ at $54^{\circ} \mathrm{C}, 2-\mathrm{min}$ extension at $72^{\circ} \mathrm{C}$, and a final extension step of $10 \mathrm{~min}$ at $72^{\circ} \mathrm{C}$. PCR products were electrophoresed through $2 \%$ agarose gel to detect indels.

Data analysis

Two different analyses were performed to identify possible structures in the Norway spruce populations. The first method, principal coordinates analysis (PCA) was done to delineate genetically similar populations based solely on population means and variances without using any geographic information. PCA was run using GeneAlEX 6.2 (Peakall and Smouse 2006). To investigate patterns of genetic subdivision, we applied spatial analysis of molecular variance (SAMOVA 1.0, Dupanloup et al. 2002). SAMOVA is based on a simulated annealing procedure that aims to maximize the proportion of total genetic 
Fig. 1 Spatial distribution of Mt15-D02 mitotypes detected in Białowieża Forest

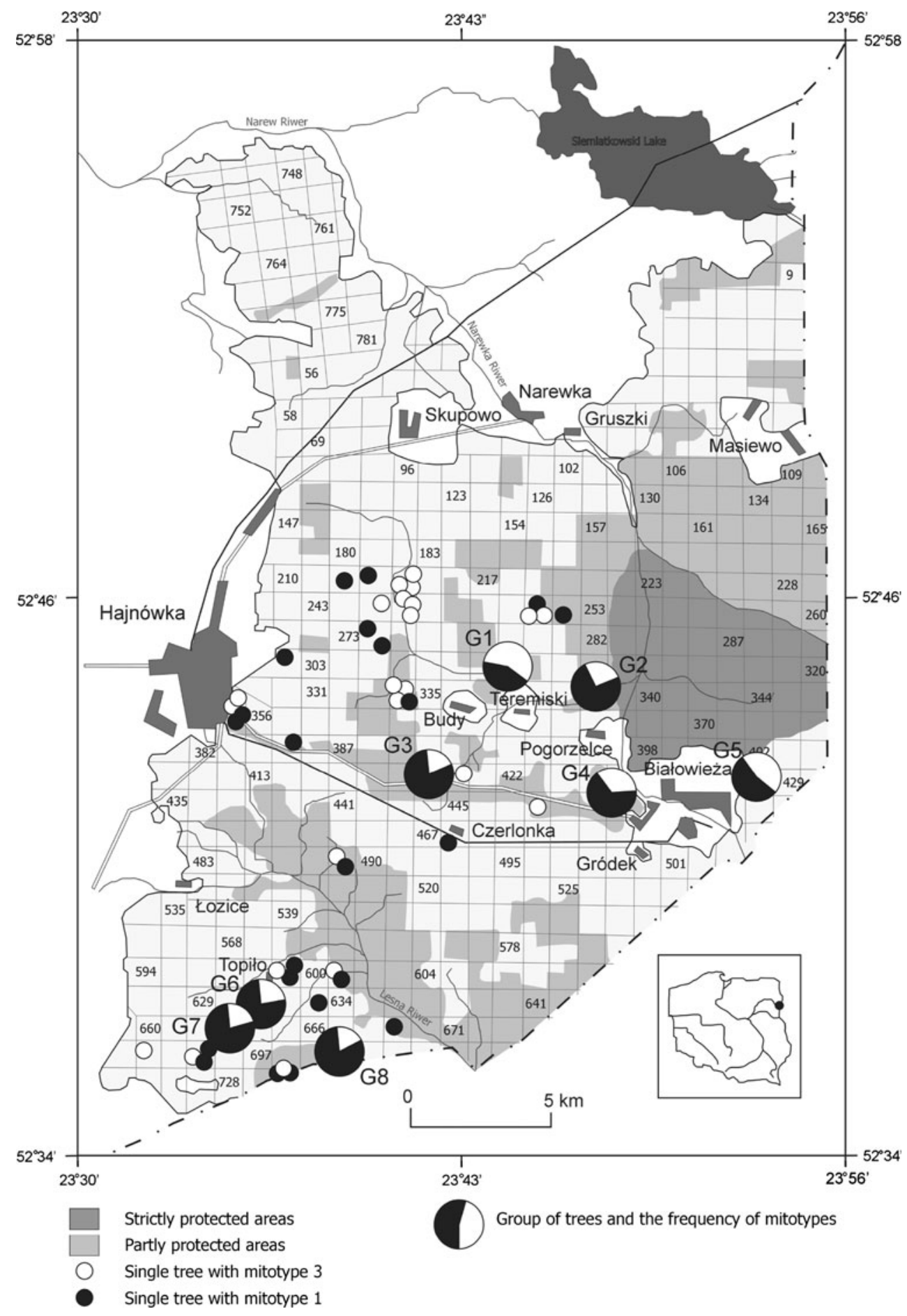

variance due to differences between groups of populations $\left(F_{\mathrm{CT}}\right)$. It seeks the composition of a user-defined number of $K$ groups of geographically adjacent populations that maximizes $F_{\mathrm{CT}}$. We determined the most likely number of $K$ groups by repeatedly running SAMOVA with variable numbers of groups and by choosing the number resulting in a maximum $F_{\mathrm{CT}}$ value. The configuration with the largest $F_{\mathrm{CT}}$ value among the 100 tested was retained as the best grouping of populations. Moreover, we tested for the presence of correlation between geographic and genetic distance performing a Mantel's test using the procedure of Smouse et al. (1986) implemented within the software GenAIEx 6 (Peakall and Smouse 2006). Statistical significance of the values was obtained via 10,000 random permutations. 
Table 1 Mt15-D02 mitotypes detected among single Norway spruce trees in Białowieża Forest

\begin{tabular}{|c|c|c|c|c|}
\hline \multirow[t]{2}{*}{ Forest range } & \multirow[t]{2}{*}{ Forest compartment } & \multirow[t]{2}{*}{ Number of trees } & \multicolumn{2}{|c|}{ Trees per mitotype } \\
\hline & & & Mitotype 1 & Mitotype 3 \\
\hline \multirow[t]{2}{*}{ Teremiski } & 251 & 3 & 1 & 2 \\
\hline & 252 & 1 & 1 & 0 \\
\hline \multirow[t]{7}{*}{ Postołowo } & 212 & 1 & 1 & 0 \\
\hline & 213 & 1 & 1 & 0 \\
\hline & 214 & 3 & 0 & 3 \\
\hline & 245 & 1 & 0 & 1 \\
\hline & 246 & 3 & 0 & 3 \\
\hline & 274 & 2 & 1 & 0 \\
\hline & 302 & 1 & 1 & 0 \\
\hline \multirow[t]{5}{*}{ Kryniczka } & 334 & 4 & 1 & 3 \\
\hline & 355 & 4 & 2 & 2 \\
\hline & 385 & 1 & 1 & 0 \\
\hline & 420 & 1 & 1 & 0 \\
\hline & 448 & 1 & 0 & 1 \\
\hline \multirow[t]{2}{*}{ Czerlonka } & 468 & 1 & 1 & 0 \\
\hline & 489 & 1 & 1 & 1 \\
\hline \multirow[t]{2}{*}{ Olszanka } & 599 & 3 & 2 & 1 \\
\hline & 601 & 2 & 1 & 1 \\
\hline Topiło & 633 & 1 & 1 & 0 \\
\hline \multirow[t]{3}{*}{ Słobódka } & 693 & 1 & 0 & 1 \\
\hline & 695 & 3 & 2 & 1 \\
\hline & 730 & 3 & 2 & 1 \\
\hline
\end{tabular}

\section{Results}

In the entire sample set, we detected three size variants the mt15-D02 locus: mitotype $1(1,249 \mathrm{bp})$, mitotype 2 (1,117 bp), and mitotype 3 (753 bp) (GenBank accession number HM047107). Mitotypes 1 and 3 occurred in Białowieża Forest (Fig. 1; Tables 1, 2). Mitotype 1 clearly predominated in the investigated area, reaching $64.8 \%$ of the sample set, while mitotype 3 was $35.2 \%$ of sample set. Both mitotypes occurred in productive stands as well as in stands under partial protection, and in the strict reserve in Białowieża NP. Mitotype 1 predominated in all groups of trees except the group G1 located most northerly in compare to the rest of groups of trees. There seems to be tendency of clustering of the Carpathian mitotype 1 in the southern part and northern mitotype 3 more toward northern part of Białowieża (Fig. 1). It mirrors the directions of proceeding recolonization.

All studied European population was monomorphic, and all three mitotypes were noted among those populations (Table 3). The three mitotypes distinctively separated the Norway spruce originating in north and northeastern Europe (mitotype 3) from those that originated in central and southeastern Europe (mitotypes 1 and 2). In the boreal range spruce population (Finland, Sweden, Latvia, and Estonia), only mitotype 3 was detected (Table 3 ). Within the southern part of the Norway spruce range, mitotypes 1 and 2 occurred (Table 3). Mitotype 1 was present in populations from Romania and Ukraine, while German populations from the Ore Mountains were fixed for mitotype 2. One Ukrainian population UKRA_A was fixed for northern mitotype 3 .

The present study confirms the existence of a genetically distinct set of populations within the Norway spruce range. The geographic distribution of mitotypes appeared to be essentially non-random. A Mantel test indicated significant relationship between genetic and geographic distance (Rxy $=0.308, P<0.01)$. Geographic structure was confirmed by SAMOVA as well. The highest value of the $F_{\mathrm{CT}}=0.723$ was reached at $K=3$. All populations from Białowieża Forest were included into group of populations from southern range, along with UkraineB, UkraineC, RomaniA, and RomaniaB. Those populations are derived from Eastern Carpathian refugium. German populations (Ore Mountains, southern Germany) fixed for mitotype 2 formed a distinct group, as well as all populations from boreal range. Northern group consists of also contains UkraineA in which mitotype 3 was fixed.

PCA identified four distinct groups of populations (Fig. 2). First principle component explained $82.39 \%$ of total variations while the second $15.66 \%$. Populations from 
Table 2 Frequency of mitotypes among groups of trees from Białowieża Forest

\begin{tabular}{lrll}
\hline Groups & $N$ trees & \multicolumn{2}{l}{ Percent trees per mitotype } \\
\cline { 3 - 4 } & & Mitotype 1 & Mitotype 3 \\
\hline G 1 & 7 & 42.9 & 57.1 \\
G 2 & 42 & 73.9 & 26.1 \\
G 3 & 5 & 80 & 20 \\
G 4 & 38 & 65.8 & 34.2 \\
G 5 & 48 & 54.2 & 45.8 \\
G 6 & 21 & 76.2 & 23.8 \\
G 7 & 9 & 77.8 & 22.2 \\
G 8 & 21 & 81 & 19 \\
\hline
\end{tabular}

boreal range, southern range, and from Białowieża Forest were grouped separately. Populations from Germany carrying mitotype 2 are distinct from other southern populations that are supposed to originate from the Carpathian refugium. Similarly to SAMOVA results, within the group of populations from northern range, population from Ukraine (Ukra_A) was located as this population was fixed for mitotype 3.

\section{Discussion}

Our study confirms the results of previous preliminary genetic studies indicating the co-occurrence in Białowieża of mitotypes 1 and 3, specific to the Eastern Carpathian and
Western Russian refugia, respectively (Dering and Lewandowski 2009). These findings are in contrast to those of paleobotanical studies; although paleobotanical studies prove the existence of a hybrid zone between the southern and northern spruce colonization pathways, they do not support the spread of spruce of Carpathian origin far into the northern range (Latałowa and Van der Knaap 2006). The numerical superiority of the Carpathian mitotype in Białowieża is also clearly seen in the hybrid zone between recolonization pathways (Dering and Lewandowski 2009). The occurrence of Carpathian spruce in Białowieża supports genetic affinity of Białowieża to this hybrid zone, as was proposed previously (Jurkevič and Parfenov 1966).

The inconsistency in the pattern of Norway spruce Holocene migration in this part of Europe that was revealed by pollen and genetic data may be ascribed to either one of the two possibilities: (1) our genetic analysis indicated Norway spruce planting, or (2) paleobotanical analyses alone were unable to reveal some of the details of the Norway spruce complex migration dynamics in this region.

The simplest explanation, one could argue, is that artificial regeneration occurred with nonlocal material. Many spruce monoculture plantations were established in Europe during the 19th century, frequently using foreign seeds sources (Sokołowski 1901; Schmidt-Vogt 1977; Mijal and Kulis 2004; Dering 2008; Main-Knom et al. 2009). It is possible that some of the present forest tree stands in Europe established in those times are of nonlocal origin (Stainer 1894; Chodzicki 1935). For example, from 1899 to 1949 , over $88,000 \mathrm{~kg}$ of Norway spruce seeds were

Table 3 Mitotypes detected and their frequency among European populations of Norway spruce

\begin{tabular}{|c|c|c|c|c|c|}
\hline \multirow[t]{2}{*}{ Site } & \multirow[t]{2}{*}{ Coordinates } & \multirow[t]{2}{*}{$N$ trees } & \multicolumn{3}{|c|}{ Percent trees per mt15-D02 mitotype } \\
\hline & & & 1 & 2 & 3 \\
\hline \multicolumn{6}{|l|}{ Boreal range } \\
\hline Finland (FIN_A) & $66^{\circ} 29^{\prime} \mathrm{N}, 25^{\circ} 43^{\prime} \mathrm{E}$ & 23 & 0 & 0 & 100 \\
\hline Finland (FIN_B) & $66^{\circ} 04^{\prime} \mathrm{N}, 24^{\circ} 48^{\prime} \mathrm{E}$ & 7 & 0 & 0 & 100 \\
\hline Sweden (SWEDEN) & $60^{\circ} 06^{\prime} \mathrm{N}, 18^{\circ} 48^{\prime} \mathrm{E}$ & 12 & 0 & 0 & 100 \\
\hline Aland Isles (ALAND) & $60^{\circ} 15^{\prime} \mathrm{N}, 19^{\circ} 54^{\prime} \mathrm{E}$ & 9 & 0 & 0 & 100 \\
\hline Estonia (ESTONIA) & $58^{\circ} 01^{\prime} \mathrm{N}, 26^{\circ} 28^{\prime} \mathrm{E}$ & 11 & 0 & 0 & 100 \\
\hline Latvia (LATVIA) & $56^{\circ} 40^{\prime} \mathrm{N}, 24^{\circ} 41^{\prime} \mathrm{E}$ & 11 & 0 & 0 & 100 \\
\hline \multicolumn{6}{|l|}{ Southern range } \\
\hline Ukraine (UKRA_A) & $51^{\circ} 29^{\prime} \mathrm{N}, 25^{\circ} 45^{\prime} \mathrm{E}$ & 15 & 0 & 0 & 100 \\
\hline Ukraine (UKRA_B) & $51^{\circ} 31^{\prime} \mathrm{N}, 25^{\circ} 46^{\prime} \mathrm{E}$ & 13 & 100 & 0 & 0 \\
\hline Ukraine (UKRA_C) & $51^{\circ} 33^{\prime} \mathrm{N}, 23^{\circ} 45^{\prime} \mathrm{E}$ & 10 & 100 & 0 & 0 \\
\hline Romania (ROMA_A) & $46^{\circ} 45^{\prime} \mathrm{N}, 25^{\circ} 20^{\prime} \mathrm{E}$ & 20 & 100 & 0 & 0 \\
\hline Romania (ROMA_B) & $46^{\circ} 15^{\prime} \mathrm{N}, 25^{\circ} 45^{\prime} \mathrm{E}$ & 12 & 100 & 0 & 0 \\
\hline Germany (GERM_A) & $50^{\circ} 36^{\prime} \mathrm{N}, 13^{\circ} 09^{\prime} \mathrm{E}$ & 9 & 0 & 100 & 0 \\
\hline Germany (GERM_B) & $50^{\circ} 37^{\prime} \mathrm{N}, 13^{\circ} 28^{\prime} \mathrm{E}$ & 10 & 0 & 100 & 0 \\
\hline Germany (GERM_C) & $50^{\circ} 43^{\prime} \mathrm{N}, 10^{\circ} 45^{\prime} \mathrm{E}$ & 10 & 0 & 100 & 0 \\
\hline Germany (GERM_D) & $50^{\circ} 40^{\prime} \mathrm{N}, 11^{\circ} 05^{\prime} \mathrm{E}$ & 10 & 0 & 100 & 0 \\
\hline
\end{tabular}




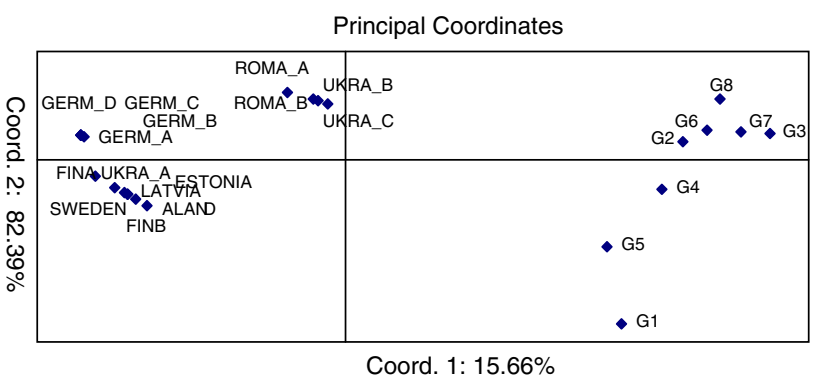

Fig. 2 Distribution of groups of Picea abies populations delineated by PCA

imported to Sweden from Germany, Denmark, Finland, and other unknown countries (Laikre et al. 2006). However, recent environmental history studies indicated that up to the eighteenth century, human exploitation in Białowieża Forest was small-scale, and deforested areas accounted for only 5-10\% of the forest area (Samojlik et al. 2007). The territory of Białowieża Forest was under strict protection from the fifteenth century onward; thus, there was only limited usage of the forest (mostly hunting and less tree felling). The forest began to suffer heavier losses since the end of the eighteenth century, when export of the most valuable timber began. In the nineteenth century, a major transformation of the forest took place due to devastation caused by massive game stocking, which disturbed and altered the natural forest communities (Faliński 1968). However, it seems that up until 1888, artificial regeneration was not used in Białowieża (Genko 1902).

We did not find mitotype 2 in Białowieża, although it is found in the adjacent hybrid zone (Dering 2008). However, Norway spruce with mitotype 2 is thought to be allochthonous for this part of the spruce range (Dering 2008; Litkowiec et al. 2009). In contrast, mitotype 2 was found to be fixed in populations from the Ore Mountains in Germany. It is also occasionally detected in some of the stands in northern Poland that were established in the nineteenth century by German foresters (Dering 2008). Maghuly et al. (2006) reported high frequencies of mitotype 2 in western Austria, while mitotype 1 predominated in eastern Austria. Taken together, these findings suggest that mitotype 2 may be found in Norway spruce populations derived from other southern refugia in addition to the Carpathian refugium. This pattern of population subdivision was supported by the SAMOVA analysis. Tollefsrud et al. (2008) have proved that within the southern Norway spruce range, significant structuring of genetic variation exists and several distinct refugia can be defined.

Based on the findings of our study, we conclude that the Eastern Carpathian spruce is probably native to Białowieża. SAMOVA grouped populations from Białowieża with those from the southern range though this territory is located within the northern Norway spruce range. It is because mitotype 1 predominates in Białowieża. In fact, Białowieża Forest is a part of hybrid zone formed after ranges merged. Fossil pollen maps do not fully support these conclusions. The postglacial history of the Norway spruce in northeastern Europe is complex, and pollen analysis may be an insufficient tool for tracing changes in the limits of tree ranges, particularly in the early stages of succession on a microscale (Birks and Birks 2000). Macrofossil analysis would be an important addition to the information gained from pollen analysis; however, although they have been found in this region, they are not abundant and their origin has not yet been ascertained. The development of new techniques to study ancient DNA may provide the tools to solve this problem in the future (Gugerli et al. 2005).

In populations from Ukraine located near the UkrainianByelorussian border (Wolynian Polesye), both mitotypes were found: two populations were fixed for mitotype 1 and one for mitotype 3 (Table 3). Previously, this area was thought to be the continuation of "spruceless zone" eastward. Latałowa and Van der Knaap (2006) based on palynologic studies do not support the migration of spruce from Carpathian refugium to Byelorussia. However, occurrence of both mitotypes in Białowieża and in north-western Ukraine seems to contradict this. Based on our results, migration of the Carpathian to Byelorussia seems probable but more detailed studies within this region are needed.

Białowieża is a particularly valuable example of the lowland forests that once dominated central Europe that need to be protected, on a genetic level as well as on a macro level. The occurrence of the Norway spruce of Eastern Carpathian origin indicates that Białowieża is part of the hybrid zone that was formed after the merging of migration pathways (Latałowa and Van der Knaap 2006; Dering and Lewandowski 2009). There is much interest in European hybrid zones like the one in our study, because of their important evolutionary role in the redistribution of genetic information (Hewitt 2000).

Acknowledgments We thank Monika Litkowiec and Maria Ratajczak for excellent laboratory work. This work was partly supported by funding from the Ministry of Science and Higher Education in Poland (2P0L 014 30).

Open Access This article is distributed under the terms of the Creative Commons Attribution Noncommercial License which permits any noncommercial use, distribution, and reproduction in any medium, provided the original author(s) and source are credited.

\section{References}

Birks HH, Birks HJB (2000) Future uses of pollen analysis must include plant macrofossils. J Biogeogr 27:31-35

Chodzicki E (1935) Leśno-hodowlane oraz leśno-polityczne refleksje oparte na wrażeniach z wycieczki Oddziału Warszawskiego PTL do lasów Dóbr Trzebień. Sylwan 1, 5:175-181, 225-234 
Dering M (2008) Postglacial migration of Norway spruce [Picea abies (L.) Karst.] in Poland based on molecular markers. PhD thesis, Institute of Dendrology, Polish Academy of Sciences, p 103

Dering M, Lewandowski A (2009) Finding the meeting zone: where have the northern and southern ranges of Norway spruce overlapped? For Ecol Manage 259:229-235

Dupanloup I, Schneider S, Excoffier L (2002) A simulated annealing approach to define the genetic structure of populations. Mol Ecol 11:2571-2581

Faliński JB (1968) National Park in Białowieża. PWN, Warsaw, p 489

Genko N (1902) Charakteristika Belovežskoj Pušči i istoričeskoe o nej svedenija. Lesnoj Žurnal 32:1009-1056, 1269-1302

Giertych M (1973) Przyczynek do dyskusji o zasięgach i pochodzeniu świerka w Polsce. (In Polish with English Summary). Sylwan 117:14-25

Gugerli F, Parducci L, Petit RJ (2005) Ancient plant DNA: review and prospects. New Phytol 166:409-418

Hewitt G (2000) The genetic legacy of the quaternary ice ages. Nature 405:907-913

Jurkevič J, Parfenov VI (1966) Świerkowe lasy Polesia. (In Polish). Sylwan 110:1-30

Laikre L, Palme A, Josefsson M, Utter F, Ryman N (2006) Release of alien populations in Sweden. Ambio 35:255-261

Latałowa M, Van der Knaap WO (2006) Late Quaternary expansion of Norway spruce [Picea abies (L.) Karst.] in Europe according to pollen data. Quat Sci Rev 25:2780-2805

Litkowiec M, Dering M, Lewandowski A (2009) Utility of two mitochondrial markers for identification of Picea abies refugial origin. Dendrobiology 61:65-71

Maghuly F, Nittinger F, Pinsker W, Proznik W, Fluch S (2006) Differentiation among Austrian populations of Norway spruce [Picea abies (L.) Karst.] assayed by mitochondrial DNA markers. Tree Genet Genomes 3:199-206

Main-Knom M, Hostert P, Kozak J, Kuemmerle T (2009) How pollution legacies and land use histories shape post-communist forest cover trends in the Western Carpathians. For Ecol Manage 258:60-70

Mijal L, Kulis M (2004) Threats for Norway spruce stands in Ustroń Forest range. Leśne Prace Badawcze 1:140-143

Peakall R, Smouse PE (2006) GENALEX 6: genetic analysis in Excel. Population genetic software for teaching and research. Mol Ecol Notes 6:288-295

Samojlik T, Jędrzejewska B, Krasnodębski D, Dulinicz M, Olczak H (2007) Man in ancient forest. Academia 4:36-37

Schmidt-Vogt H (1977) Die Fichte. Band 1. Hamburg, Verlag Paul Parey

Smouse PE, Long JC, Sokal RR (1986) Multiple regression and correlation extensions of the Mantel test of matrix correspondence. Syst Zool 35(4):627-632

Sokołowski S (1901) Z lasów Podolskich. Sylwan 19:1-11, 39-47, 76-83, 133-138, 176-181, 291-300, 324-332

Sperisen C, Büchler U, Gugerli F, Mátyás G, Geburek T, Vendramin GG (2001) Tandem repeats in plant mitochondrial genomes: application to the analysis of population differentiation in the conifer Norway spruce. Mol Ecol 10:257-263

Środoń A, Tobolski K (2007) Paleorecord of Norway spruce. In: Tjoelker MG, Boratyński A (eds) Biology and ecology of Norway spruce. Springer, Dordrecht, pp 1-8

Stainer J (1894) Seed extraction and trade with seeds of forest tree species. Sylwan 12:425-432

Tollefsrud MM, Kissling R, Gugerli F, Johnsen $\varnothing$, Skrøppa T, Cheddedi R, Van der Knaap WO, Latałowa M, Terhurne-Berson R, Litt T, Geburek T, Brochman C, Sperisen C (2008) Genetic consequences of glacial survival and postglacial colonization in Norway spruce: combined analysis of mitochondrial DNA and fossil pollen. Mol Ecol 17:4134-4150

Tollefsrud MM, Sønstebø JH, Brochmann C, Jonsen O, Skrøppa T, Vendramin GG (2009) Combined analysis of nuclear and mitochondrial markers provide a new insight into the genetic structure of North European Picea abies. Heredity 102:549-562 